\title{
Perbandingan Pemberian Ekstrak Daun Ketepeng Cina (Cassia alata L.) dengan Ketokonazol 2\% terhadap Zona
}

\section{Hambat Malassezia Furfur}

Rahmawati $^{1 *}$, Zulfiyah Surdam², Mochammad Erwin Rachman³, Rani Meiriska Sari ${ }^{4}$

${ }^{1}$ Departemen Radiologi, Fakultas Kedokteran, Universitas Muslim Indonesia, Makassar, Indonesia

2 Departemen Anatomi, Fakultas Kedokteran, Universitas Muslim Indonesia, Makassar, Indonesia

${ }^{3}$ Departemen Fisiologi, Fakultas Kedokteran, Universitas Muslim Indonesia, Makassar, Indonesia

${ }^{4}$ Mahasiswa Program Studi Sarjana Kedokteran, Universitas Muslim Indonesia, Makassar, Indonesia

*Corresponding Author. E-mail: atierwin@ gmail.com, Mobile number: +62 852-5568-5888

\begin{abstract}
ABSTRAK
Latar Belakang: Di Indonesia, penyakit pityriasis versicolor mempunyai insiden yang cukup tinggi. Terapi topikal direkomendasikan untuk infeksi lokal karena dermatomikosis superfisial yang hidup pada jaringan kulit. Penelitian ini bertujuan untuk mengetahui pengaruh pemberian ekstrak daun ketepeng cina (Cassia alata L.) dan ketokonazol $2 \%$ terhadap zona hambat malassezia furfur.

Metode : Pada penelitian ini terdapat tiga kelompok yaitu, kelompok yang diberi perlakuan dengan menggunakan ekstrak daun ketepeng cina (Cassia alata L.) dengan konsentrasi 50\%, 75\%, dan 100\%, serta kelompok kontrol yang diberi perlakuan dengan menggunakan ketokonazol $2 \%$ yang sebelumnya semua kelompok baik perlakuan maupun kontrol ditanam sediaan jamur malassezia furfur pada medium agar di cawan petri, lalu menggunakan metode disc diffusion.

Hasil : Diameter zona hambat ekstrak daun ketepeng cina (Cassia alata L.). Konsentrasi $50 \%$ menunjukkan hasil zona hambat sedang pada Malassezia furfur yaitu $9 \mathrm{~mm}$, sedangkan pada konsentrasi 75\% menunjukkan hasil 11 mm dan konsentrasi $100 \%$ menunjukkan hasil $13 \mathrm{~mm}$ dengan interpretasi zona hambat kuat pada malassezia furfur.

Kesimpulan: Ekstrak daun ketepeng cina (Cassia alata L.) dengan konsentrasi $75 \%$ dan $100 \%$ memiliki daya hambat kuat tetapi tidak sebanding dengan ketokonazol $2 \%$ dalam menghambat pertumbuhan jamur malassezia furfur.
\end{abstract}

Kata Kunci : Cassia alata L.; zona hambat; malassezia furfur; ketokonazol 2\%

Article history:

Received: 01 Mei 2020

Accepted: 23 Juni 2020

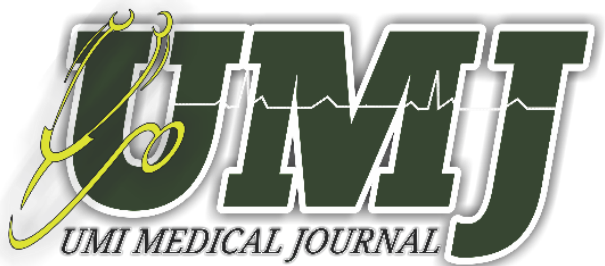

Published: 28 Desember2020

\section{Published by :}

Fakultas Kedokteran

Universitas Muslim Indonesia

Phone:

+6282293330002
Address:

Jl. Urip Sumoharjo Km. 5 (Kampus II UMI)

Makassar, Sulawesi Selatan.

Email:

medicaljournal@umi.ac.id 


\section{ABTRACT}

Background: In Indonesia, pityriasis versicolor has a high incidence. Topical therapy is recommended for local infections due to superficial dermatomycoses that live in the skin tissue. This study aims to determine the effect of giving Chinese ketepeng leaf extract (Cassia alata L.) and ketoconazole 2\% on the inhibition zone of malassezia furfur.

Methods: In this study, there were three groups, namely the group that was treated using Chinese ketepeng leaf extract (Cassia alata L.) with a concentration of $50 \%, 75 \%$, and $100 \%$, and the control group treated using ketoconazole $2 \%$ which Previously, all groups, both treatment and control, were planted with malassezia furfur on agar medium in a petri dish, then used the disc diffusion method.

Results: Diameter of inhibition zone of Chinese ketepeng leaf extract (Cassia alata L.). The concentration of 50\% shows the results of the moderate inhibition zone in Malassezia furfur that is $9 \mathrm{~mm}$, while at a concentration of $75 \%$ shows a result of $11 \mathrm{~mm}$ and a concentration of $100 \%$ shows a result of $13 \mathrm{~mm}$ with the interpretation of the strong inhibition zone in Malassezia furfur.

Conclusion: Extract of Chinese ketepeng (Cassia alata L.) leaves with a concentration of $75 \%$ and $100 \%$ has a strong inhibitory power but is not comparable to ketoconazole $2 \%$ in inhibiting the growth of malassezia furfur fungus.

Keywords: Cassia alata L.; obstacles zone; malassezia furfur; ketoconazole $2 \%$

\section{PENDAHULUAN}

Di Indonesia, penyakit Pityriasis versicolor mempunyai insiden yang cukup tinggi. Laporan jumlah penderita dermatomikosis superfisial khususnya penyakit Pityriasis versicolor di Indonesia belum terlalu spesifik, namun dari beberapa rumah sakit menyatakan bahwa jumlah kasus dermatomikosis superfisial non dermatofitosis Pityrisasis versicolor cukup banyak ditemukan. Penyakit ini banyak ditemukan pada penduduk sosial ekonomi yang rendah. ${ }^{1}$

Pengobatan Pityriasis versicolor dapat diberikan secara sistemik maupun topikal. Pengobatan topikal terutama ditujukan untuk penderita dengan lesi yang minimal. ${ }^{2}$ Terapi topikal direkomendasikan untuk infeksi lokal karena dermatomikosis superfisial yang hidup pada jaringan kulit. Pada golongan imidazole terdiri dari ketokonazol, mikonazol, klotrimazol, dan hanya ketokonazol yang paling banyak digunakan. Ketokonazol merupakan turunan imidazol sintetik yang bersifat lipofilik dan larut dalam air pada pH asam. Ketokonazol 2\% krim digunakan untuk infeksi jamur di kulit tak berambut seperti dermatomikosis superfisial, dengan dosis dan lamanya pengobatan tergantung dari kondisi pasien. ${ }^{3,4}$

Masyarakat umumnya menggunakan bagian tumbuhan yang meliputi akar, batang, daun, bunga atau bijinya sebagai ramuan obat-obatan. Salah satu tumbuhan yang digunakan sebagai sumber obat tradisional adalah tumbuhan ketepeng cina (Cassia alata L.). Selama ini masyarakat memanfaatkannya sebagai obat untuk penyakit kulit yang disebabkan oleh jamur, seperti kurap, panu, kutu air, dan lain-lain. Secara ilmiah, hal ini dikarenakan adanya kandungan zat kimia yang terdapat di dalam ketepeng cina (Cassia alata L.) 
yang bersifat antimikrobial. ${ }^{5}$ Daun ketepeng cina dapat digunakan sebagai obat secara tradisional karena adanya kandungan kimia yang terdapat di dalamnya seperti rein aloe emodina, rein aloe, emodina diantron, rein aloe emodina asam krisofanat (dehidroksi metil antroquinone) dan tannin. Selain itu, alkaloida, flavonoida, dan antrakuinon juga terdapat di dalamnya. ${ }^{6}$

Berdasarkan latar belakang diatas, maka penulis tertarik untuk membandingkan pemberian ekstrak daun ketepeng cina (Cassia alata L.) dan ketokonazol 2\% terhadap zona hambat malassezia furfur.

\section{METODE PENELITIAN}

Desain penelitian yang digunakan dalam penelitian ini adalah experimental design dengan posttest-only control group design. Di dalam design ini terdapat tiga kelompok yaitu, kelompok yang diberi perlakuan dengan menggunakan ekstrak daun ketepeng cina (Cassia alata L.) dengan konsentrasi 50\%, 75\%, dan $100 \%$, serta kelompok kontrol yang diberi perlakuan dengan menggunakan ketokonazol $2 \%$ yang sebelumnya semua kelompok baik perlakuan maupun kontrol ditanam sediaan jamur malassezia furfur pada medium agar di cawan petri. Kemudian didalam penelitian ini peneliti menggunakan metode disc diffusion. Metode ini digunakan untuk menguji efektivitas pemberian ekstrak daun ketepeng cina (Cassia alata L.) sebagai anti jamur terhadap jamur malassezia furfur dengan cara mengukur zona hambat yang terbentuk.

\section{HASIL PENELITIAN}

Rerata zona hambat yang terbentuk pada berbagai konsentrasi ekstrak daun ketepeng cina (Cassia alata L.), dan ketokonazol 2\% dapat dilihat pada tabel

Tabel 1. Zona hambat ekstrak daun ketepeng cina dan ketokonazol 2\%

\begin{tabular}{|c|c|c|c|}
\hline Bahan Penelitian & Konsentrasi & $\begin{array}{c}\text { Zona hambat pada } \\
\text { Malassezia furfur } \\
\text { (mm) }\end{array}$ & $\begin{array}{c}\text { Interpretasi respon } \\
\text { hambatan } \\
\text { pertumbuhan }\end{array}$ \\
\hline \multirow{3}{*}{$\begin{array}{l}\text { Ekstrak Daun } \\
\text { Ketepeng Cina } \\
\text { (Cassia alata L.) }\end{array}$} & $50 \%$ & 9 & Sedang \\
\hline & $75 \%$ & 11 & Kuat \\
\hline & $100 \%$ & 13 & Kuat \\
\hline \multicolumn{2}{|c|}{ Ketokonazol 2\% } & 15 & Kuat \\
\hline
\end{tabular}

Berdasarkan tabel diatas, dapat dilihat bahwa pada ekstrak daun ketepeng cina (Cassia alata L.) didapatkan zona hambat yang paling tinggi pada konsentrasi ekstrak 100\% dengan rerata zona hambat sebesar $13 \mathrm{~mm}$, sedangkan zona hambat yang paling rendah yaitu pada konsentrasi $50 \%$ dengan rerata zona hambat sebesar $9 \mathrm{~mm}$. 
Pada kontrol positif menggunakan antifungi Ketokonazol 2\% didapatkan rerata zona hambat sebesar $15 \mathrm{~mm}$ yakni sensitif menghambat pertumbuhan jamur.

Berdasarkan klasifikasi zona hambat bakteri menurut David dan Stout (1971), kriteria kekuatan daya antimikroba dengan diameter zona hambatan ada yang bersifat lemah $(\leq 5 \mathrm{~mm})$, sedang $(5-10 \mathrm{~mm})$, kuat (10-20 mm) dan sangat kuat ( $\geq 20 \mathrm{~mm}$ ). Jadi dapat disimpulkan bahwa ekstrak daun ketepeng cina (Cassia alata L.) efektif menghambat pertumbuhan jamur malassezia furfur pada konsentrasi 50\%, 75\% dan $100 \%$ dengan daya hambat bakteri rerata kuat.

\section{Gambar 1. Hasil Zona Hambat yang terbentuk pada tiap konsentrasi dan Kontrol}
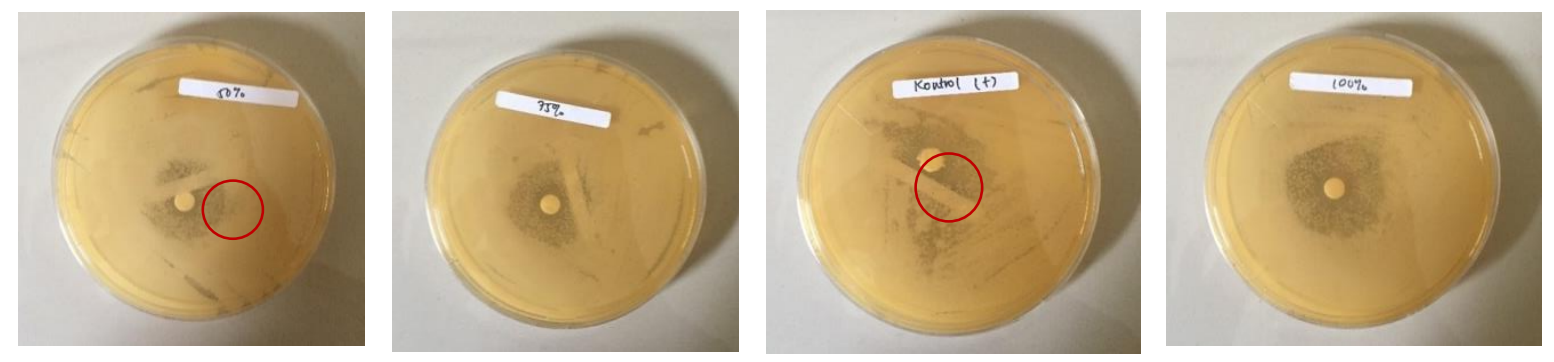

\section{PEMBAHASAN}

Penelitian ini dilakukan untuk menguji efektifitas dari ekstrak daun ketepeng cina (Cassia alata L.) terhadap pertumbuhan jamur malassezia furfur. Penelitian ini menggunakan metode disc diffusion. Sebelum dilakukan penelitian, bakteri terlebih dahulu diremajakan selama 24 jam untuk mendapatkan bakteri yang aktif karena sebelumnya bakteri yang dari dalam lemari pendingin masih dalam bentuk inaktif. Pembuatan medium ekstrak daun ketepeng cina (Cassia alata L.) masing-masing memiliki 3 cawan petri beserta 1 cawan petri berisi cakram kontrol positif ketokonazol $2 \%$.

Penelitian ini dilakukan dengan cara mengusapkan jamur malassezia furfur ke cawan petri yang sudah berisi medium agar, kemudian letakkan cakram yang sudah direndamkan ekstrak daun ketepeng cina (Cassia alata L.) masing-masing 1 cakram. Setelah semua cawan petri telah diusapkan bakteri, dilakukan inkubasi selama 24 jam sebelum hasil dibaca. 
Pada ekstrak daun ketepeng cina (Cassia alata L.) didapatkan zona hambat 9 mm pada konsentrasi $50 \%$, zona hambat $11 \mathrm{~mm}$ pada konsentrasi $75 \%$, dan zona hambat $13 \mathrm{~mm}$ pada konsentrasi 100\%,sedangkan zona hambat yang di dapatkan pada kontrol positif ketokonazol $2 \%$ adalah $15 \mathrm{~mm}$.

Pada penelitian yang dilakukan oleh Meryand Putri Gama et al. (2011), didapatkan bahwa ekstrak daun ketepeng cina (Cassia alata L.) dengan konsentrasi 50\% sebanding dengan ketokonazol 2\% dalam menghambat pertumbuhan malassezia furfur pada pityriasis versicolor secara in vitro ${ }^{7}$, sedangkan penelitian yang didapatkan oleh Delvi Rusitaini Putri et al. (2016) bahwa ekstrak daun ketepeng cina (Cassia alata L.) dengan konsentrasi 20\%,40\%, 60\%, 80\%, 100\% mampu menghambat pertumbuhan jamur malassezia furfur tetapi kurang efektif dibandingkan dengan terbinafin ${ }^{8}$. Namun, pada penelitian yang dilakukan oleh peneliti ini didapatkan hasil semua konsentrasi dari ekstrak daun ketepeng cina (Cassia alata L.) memiliki respon zona hambat yang kuat terhadap pertumbuhan jamur malassezia furfur.

Pada penelitian yang dilakukan oleh peneliti, didapatkan bahwa ekstrak daun ketepeng cina (Cassia alata L.) pada konsentrasi 50\% memiliki respon yang sedang terhadap zona hambat malassezia furfur dan tidak sebanding dengan zona hambat dari ketokonazol 2\%, sedangkan pada konsentrasi $75 \%$ dan $100 \%$ memiliki respon yang kuat terhadap zona hambat malassezia furfur tetapi masih belum efektif seperti halnya ketokonazol 2\%. Hasil penelitian ini memiliki hasil yang berbeda dengan hasil penelitian yang dilakukan oleh Meryand Putri Gama et.al (2011) yang menyatakan bahwa ekstrak daun ketepeng cina (Cassia alata L.) dengan konsentrasi 50\% sebanding dengan ketokonazol 2\%. Dalam penelitian ini didapatkan bahwa pada ekstrak daun ketepeng cina (Cassia alata L.) dengan konsentrasi $75 \%$ dan $100 \%$ memiliki interpretasi kuat tetapi belum setara dengan ketokonazol $2 \%$.

Perbedaan penelitian ini dengan penelitian sebelumnya terletak pada kontol positif, juga konsentrasi dari masing-masing ekstrak daun ketepeng cina (Cassia alata L.). dan hasil yang didapatkan juga berbedabeda di setiap penelitian,sedangkan metode yang digunakan adalah sama, yaitu dengan metode disc diffusion. 
Pada penelitian yang dilakukan oleh Farrokh Rad et al (2014), menyimpulkan bahwa ketokonazol $2 \%$ dan terbinafine $1 \%$ memiliki efek serupa untuk pengobatan pityriasis versicolor. Tetapi, penggunaan terbinafin $1 \%$ menghasilkan tingkat terapi yang lebih sukses dan tingkat kekambuhan yang lebih rendah dibandingkan dengan ketokonazol $2 \% .^{9}$

Kandungan antrakuinon memiliki sifat antifungi yang bekerja secara fungistatik dengan cara menghambat pertumbuhan hifa jamur, sehingga pertumbuhan jamur terhenti. ${ }^{19}$ Antrakuinon yang di dalamnya terdapat Aloe emodina ini merupakan zat warna yang dapat menjadi pencahar. Kandungan glikosida antrakuinon pada daun ini dapat menghambat pertumbuhan hifa jamur sehingga pertumbuhan jamur menjadi terhenti. Hal ini menunjukkan adanya sifat fungistatik. ${ }^{10}$

Flavonoid mengandung senyawa polifenol yang sering terdapat pada tanaman dan memiliki imunomodulasi dan antioksidan. Flavonoid berfungsi untuk anti-inflamasi, antialergi dan antimikrobia. Bioaktivitas pada flavonoid yang terdiri dari struktur kimia dan mekanismenya dapat menghambat sistem enzim yang mengganggu aktivasi sel jamur sehingga proses pemanjangan hifa menjadi terhambat dan tidak dapat berkembang biak. Hal ini menyebabkan jamur akan mudah mati. ${ }^{11}$

Alkaloid sebagai antifungi akan menyebabkan kerusakan membran sel. Alkaloid ini akan berikatan kuat dengan ergosterol dan membentuk lubang yang menyebabkan kebocoran membran sel. Hal ini mengakibatkan kerusakan yang tetap pada sel dan kematian sel pada jamur. ${ }^{12}$

Senyawa aktif antijamur yang berasal dari daun ketepeng cina bersifat polar. Senyawa ini mampu berikatan dengan asam amino dari protein membentuk produk konjugasi yang bersifat hidrofilik. Produk konjugasi yang terbentuk akan menghambat metabolisme sel karena senyawa yang terbentuk mengubah struktur asam amino yang fungsi awalnya adalah untuk metabolisme sel. Senyawa fenolik mampu mengganggu proses respirasi Cercospora personatum di dalam memperoleh energi, yaitu dengan menghambat aktivitas enzim-enzim respirasi aerobik, enzim-enzim respirasi dalam siklus kreb, sistem transfer elektron dan dalam membran sel, hal ini berakibat rendahnya energi yang dihasilkan dan akan menghambat pertumbuhan sel. ${ }^{13}$ 
Berdasarkan hasil penelitian yang telah dilakukan oleh Riza Linda et al. (2011), menyimpulkan bahwa konsentrasi yang efektif dari ekstrak daun ketepeng cina (Cassia alata L.) dalam menghambat pertumbuhan jamur cercospora personatum adalah konsentrasi 3\%. Aktivitas fungisida ekstrak daun ketepeng cina terhadap jamur Cercospora personatum di kategorikan dalam tingkatan "kuat" yaitu di atas $50 \%$ mulai pada konsentrasi ekstrak 3\%.

Banyak faktor yang dapat mempengaruhi hasil zona hambat dari penelitian ini, faktor ini dapat berasal dari medium, jamur uji, serta pada saat proses perlakuan. Faktor yang berasal dari medium yaitu kedalaman dari medium agar, $\mathrm{pH}$, dan suhu penyimpanan dari medium tersebut. Faktor yang berasal dari bakteri ialah jenis bakteri, respon bakteri terhadap sampel yang diujicobakan, serta asal dari bakteri tersebut, apakah merupakan bakteri biakan atau dari spesimen. Faktor pada saat proses perlakuan, seperti perhitungan konsentrasi ekstrak, perbedaan waktu antara inokulasi dan pengaplikasian cakram, kondisi saat inokulasi dan inkubasi, serta adanya kontaminasi bakteri yang dapat berasal dari ventilasi udara atau pada saat pengujian.

\section{KESIMPULAN}

Ekstrak daun ketepeng cina (Cassia alata L.) pada konsentrasi 75\%, dan 100\% memliki daya hambat kuat, tetapi tidak sebanding dengan ketokonazol $2 \%$ dalam menghambat pertumbuhan jamur malassezia furfur.

\section{DAFTAR PUSTAKA}

1. Crowe, M. A.2009.Journal Emedicine Dermatology,Tinea versicolor.

2. Madani F, Harahap M, editor.2000.Infeksi Jamur Kulit. In: Ilmu Penyakit Kulit. Jakarta: Hipokrates

3. Rushing ME. 2009. Tinea corporis. US: Medical College of Georginia.

4. Habif, P. Thomas.2016.Clinical Dermatology: A Color Guide to Diagnosis and Therapy.,USA:Elsevier Inc. Pages: 532

5. A.N.S. Thomas, 1992, Tanaman Obat Tradisional 2. Yogyakarta: Kanisius.

6. Sule WF, Okonko IO, Joseph TA, Ojezele MO, Nwanze JC, Alli JA.2010. In-vitro antifungal activity of Senna alata Linn. crude leaf extract. Res J Biol Sci.; Pages:275-84. 
7. Putri,D. R. 2016. Perbandingan Efektivitas Terbafin dengan Ekstrak Daun Ketepeng Cina (Cassia alata L) terhadap Pertumbuhan Jamur (Malassezia furfur) sebagai Etiologi Pityriasis versicolor. Universitas Lampung

8. Sihombing, Maria Anna; Winarto and Saraswati, Indah (2018) Uji Efektivitas Antijamur Ekstrak Biji Pepaya (Carica papaya L.) Terhadap Pertumbuhan Malassezia furfur Secara In Vitro

9. Rad, Farrokh, et al. 2014. Terbinafin 1\% Cream and Ketoconazole 2\% Cream in the Treatment of Pityriasis Versicolor: A randomized comparative clinical trial. Pak J Med Sci

10. Anwar, A.N.D.2015.Manfaat Daun Ketepeng Cina (Cassia alata L.) sebagai Antifungi pada Tinea Pedis.Universitas Lampung

11. Rahman MS, Ali MY, Ali MU. In vitro screening of two flavonoid compounds isolated from Cassia alata L. leaves for fungicidal activities. J Bio-Sci. 2008; 16:139-42

12. Setiabudy R, Bahryn B. Farmakologi dan terapi: obat jamur. Edisi 5. Jakarta: Fakultas Kedokteran Universitas Indonesia. 2007.

13. Saunders, C.W.; Scheynius, A.; Heitman, J. Malassezia fungi are specialized to live on skin and associated with dandruff, eczema and other skin disease. PLoS Pathog.2012, 8, e1002701.

14. Mustofa A. 2014. Prevalensi Dan Faktor Resiko Terjadinya Pityriasis versicolor Pada Polisi Lalu Lintas Kota Semarang. Skripsi. Semarang: Universitas Diponogero.

15. American Academy of Pediatric, 2015, Red Book: 2015 Report of the Committee on Infectious Disease, USA. Pages: 623

16. Crowe, M. A.2009.Journal Emedicine Dermatology,Tinea versicolor.

17. Radiono S. Pytiriasis versikolor. In : Budimulja U, Kuswadji, Bramono K, Menaldi SL, Dwihastuti P, Widaty S, editors.2001 Dermatomikosis Superfisialis: Pedoman untuk Dokter dan Mahasiswa Kedokteran. Jakarta : Balai Penerbit FK UI.

18. Mustofa A. 2014. Prevalensi Dan Faktor Resiko Terjadinya Pityriasis versicolor Pada Polisi Lalu Lintas Kota Semarang. Skripsi. Semarang: Universitas Diponogero.

19. Habif, P. Thomas.2016.Clinical Dermatology: A Color Guide to Diagnosis and

20. American Academy of Pediatric, 2015, Red Book: 2015 Report of the Committee on Infectious Disease, USA. Pages: 623

21. Neelam A. V., and Howard I. M.,2017,Dermatoanthropology of Ethnic Skin and Hair,Switzerland: Springer International Publishing. Pages: 151-152

22. Oh, B.H.; Song, Y.C.; Lee, Y.W.; Choe, Y.B.; Ahn, K.J. Comparison of Nested PCR and RFLP for Identification and Classification of Malassezia Yeasts from Healthy Human Skin. Ann. Dermatol.2009, 21, 352-357. 
23. Levin NA, Delano S. Evaluation and treatment of Malassezia-related skin disorders. Cosmetic Dermatology 2015;24(3):137-45.

24. Sihombing, Maria Anna; Winarto and Saraswati, Indah (2018) Uji Efektivitas Antijamur Ekstrak Biji Pepaya (Carica papaya L.) Terhadap Pertumbuhan Malassezia furfur Secara In Vitro

25. Schwartz JR, Messenger AG, Tosti A, et al. A comprehensive pathophysiology of dandruff and seborrheic dermatitis - towards a more precise definition of scalp health. Acta Derm Venereol. 2013;93(2):131-137.

26. Poindexter GB, Burkhart CN, Morrell DS. Therapies for pediatric seborrheic dermatitis. Pediatr Ann. 2009;38(6):333-338.

27. Ooi ET, Tidman MJ. Improving the management of seborrhoeic dermatitis. Practitioner. 2014;258(1768):23-26. 